\title{
Prevalence of hepatitis $C$ virus infection in north-eastern Brazil: a population-based study
}

\author{
Maria Alice S. Zarife a,b, Luciano K. Silva ${ }^{a}$, Maria Betânia S. Silva ${ }^{a}$, \\ Gisele B. Lopes ${ }^{a}$, Maurício L. Barretoc ${ }^{c}$, Maria da Glória Teixeirac, \\ Inês Dourado ${ }^{c}$, Mitermayer G. Reis ${ }^{\mathrm{a}, *}$
}

\author{
a Laboratório de Patologia e Biologia Molecular, Centro de Pesquisas Gonçalo Moniz da FIOCRUZ, \\ R. Waldemar Falcão 121, Brotas, 40295-001 Salvador, Bahia, Brazil \\ b Laboratório Central de Saúde Pública Prof. Gonçalo Moniz (LACEN-BA), Salvador, Bahia, Brazil \\ c Instituto de Saúde Coletiva, UFBA, Salvador, Bahia, Brazil
}

Received 3 May 2005; received in revised form 1 August 2005; accepted 11 September 2005 Available online 28 December 2005

\section{KEYWORDS \\ Hepatitis C virus; \\ HCV; \\ Population-based \\ study; \\ Genotype; \\ Brazil}

\begin{abstract}
Summary In general, the prevalence and genotype distribution of hepatitis C virus (HCV) are estimated based on the ambulatory clinic or hospital population. In the present work, a population-based study was conducted to estimate the prevalence of HCV infection in Salvador, Brazil. A total of 1308 serum samples were collected from 30 'sentinel areas', and the prevalence of HCV infection was determined by ELISA and confirmed by recombinant immunoblot assay and RT-PCR. The overall prevalence of HCV infection was 1.5\% (20/1308). Prevalence was greater among those aged 35 years or older and those with more education. Genotype 3 was the most common (53.3\%), followed by genotypes 1 (40\%) and $2(6.7 \%)$. These observations are different from those found in a prior survey of hospital and ambulatory patients in Salvador, who were most frequently infected with genotype 1, followed by genotypes 3 and 2, respectively. (c) 2005 Royal Society of Tropical Medicine and Hygiene. Published by Elsevier Ltd. All rights reserved.
\end{abstract}

\section{Introduction}

Hepatitis $C$ virus (HCV) is the main aetiological agent of non-A and non-B hepatitis and is associated with chronic

\footnotetext{
Presented in part at 'Congresso da Sociedade Brasileira de Medina Tropical \& Simpósio de Antimicrobianos', Foz do Iguaçu-PR, Brazil, February 2002.

* Corresponding author.

E-mail address: miter@cpqgm. fiocruz.br (M.G. Reis).
}

infection, cirrhosis and hepatocellular carcinoma (Cochran, 1977; Roggendorf et al., 2000; Tong et al., 1995). The worldwide chronic HCV infection prevalence is estimated to be $3 \%$ (EASL, 1999), varying from $0.1 \%$ to $5 \%$ in different countries. There are approximately 175 million chronic HCV carriers in the world, an estimated 4 million of whom are in the USA and 5 million are in Western Europe. In most studies, much of the information is based on readily accessible samples such as those obtained from selection of individuals in blood banks, cases of chronic hepatitis and haemodialysis patients (Di Lallo et al., 1999). These studies do not represent the 
real prevalence of HCV infections in the general population. In Brazil, the estimated HCV prevalence is approximately $1.5 \%$; more than 2 million people are infected with the virus (Ministério da Saúde, Brasil, 1993). This estimate is based on studies performed on blood donors, such as the study in Salvador where a prevalence of $1.7 \%$ was determined (N. Santana, unpublished data). Few studies describe HCV infection prevalence in the general population in Brazil, such as the one described in São Paulo (Focaccia et al., 1998; Silva et al., 1995).

Epidemiological data suggest that the HCV genotype distribution varies between different regions (Davidson et al., 1995; Schreier et al., 1996). Genotypes 1, 2 and 3 are most prevalent in Japan, Western Europe and North America; genotype 4 in Northern and Central Africa and the Middle East; genotype 5 in South Africa; and genotype 6 in Southeast Asia (Nousbaum, 1998). In Brazil, some previous studies revealed the predominance of genotype 1 , followed by genotypes 3 and 2 (Krug et al., 1996; Oliveira et al., 1999; Silva et al., 2000).

Here we report the prevalence of HCV infection and genotype distribution in a population-based study in a large urban setting in Brazil.

\section{Materials and methods}

\subsection{Study design}

In 1998 the city of Salvador had approximately 2.3 million inhabitants, with wide differences between specific areas regarding the socio-economic status of the population and the quality of their environment. This investigation is part of a large ongoing project to estimate the incidence and prevalence of serological markers of infectious agents among residents of distinct intra-urban spaces in Salvador (capital of Bahia state, north-east Brazil), referred to as 'sentinel areas'. The sampling scheme is described in detail elsewhere (Teixeira et al., 2002). Briefly, the study population was drawn from a spatial cluster sample of 30 neighbourhoods throughout the city (sentinel surveillance areas), taken from the 1765 census tracts of Salvador (1991 census). The census tracts were selected on the basis of sanitation coverage and income level in order to represent the range of living conditions within the city. Information regarding income, sanitation and population density was supplied by the Brazilian Geography and Statistics Institute (IBGE) (http://www.ibge.gov.br) (Fundação IBGE, 1996). A census was carried out in the selected areas and identified 68749 residents. For sample size calculation, the seroprevalence of important virus infections as well as other parameters were considered and 2149 residents from the 30 sample areas were selected by random sampling without replacement and with post-stratification (Cochran, 1977). Data on area of residence, sex, age, income and educational level were collected between May and July 1998 by questionnaire. After obtaining informed consent, a blood sample was collected from 1308 individuals. Samples were anonymized and unlinked prior to laboratory analysis, and investigation of HCV seroprevalence was conducted retrospectively. It was therefore not possible to collect information subsequently regarding other important risk factors for HCV infection.
This project was approved by the Ethical Committee of the Gonçalo Moniz Research Center, FIOCRUZ.

\subsection{Laboratory tests}

Hepatitis C antibody (anti-HCV) was screened by an automated ELISA (Microparticle Enzyme Immunoassay (MEIA) System AxSYM; Abbott Diagnostics, Wiesbanden, Germany). A supplemental recombinant immunoblot assay (RIBA 3.0; Chiron, Emeryville, CA, USA) confirmatory test was performed for each sample. The procedures strictly followed the manufacturers' instructions. HCV RNA was detected by RT-PCR. Briefly, $200 \mu \mathrm{l}$ of serum was used for HCV RNA extraction by the guanidinium isothiocyanate-phenol-chloroform method (Chomezynski and Sacchi, 1987) and was then precipitated with ethanol and dried (Sambrook et al., 1989). HCV RNA was immediately doubly transcribed into CDNA and PCR was carried out (Li et al., 1995). Positivity was established by electrophoresis on a $1.5 \%$ agarose gel and staining the gel with ethidium bromide. The size of the RT-PCR product was $268 \mathrm{bp}$. The sensitivity of this PCR is approximately 100-200 UI/ml (Krajden, 2000).

The samples were considered positive when at least two tests among ELISA, RIBA and PCR were positive. Samples were genotyped by an in-house assay employing RT-nested PCR and RFLP analysis (Davidson et al., 1995).

\subsection{Statistical analysis}

Data were analysed using Epi Info 6.04d program (CDC, Atlanta, GA, USA) and STATA version 7.0 (Stata Corp., College Station, TX, USA). Frequency distributions were determined for each variable. Age was categorised from an originally continuous variable and the best single cut-off point was found to be below and above 35 years of age. Other categorical variables (and cut-off points) were: education ( $\geq 7$ years and $<7$ years of schooling); income $(\leq 2.5$ and $>2.5$ Brazilian minimum wage $(\mathrm{MW}) /$ month, approximately US\$125 at the time of our survey; $M W$ at the time of our survey was approximately US\$50.00).

We choose these cut-off points based on the social structure of the city of Salvador where the majority of the population belong to low-income groups. Neighbourhood of residence was categorised into better and worse living conditions based on the level of sanitation coverage in the neighbourhood and individual income. The $\chi^{2}$ test or the Fisher's exact test were used for comparison of proportions. Unadjusted odds ratios (OR) and $95 \% \mathrm{Cl}$ were calculated with $2 \times 2$ tables and used to explore the association of study variables and HCV prevalence.

\section{Results}

The anti-HCV seroprevalence detected by ELISA was $3.2 \%$ (42/1308) (Table 1), of which $31.0 \%$ (13/42) were also RIBA positive, $42.9 \%(18 / 42)$ were RIBA indeterminate and $26.2 \%$ $(11 / 42)$ were RIBA negative (Table 2$)$. These results point to a seroprevalence confirmed by RIBA of $1.0 \%(13 / 1308)$, with $1.4 \%(18 / 1308)$ indeterminate results. Comparing ELISA and RIBA results, we observed that RIBA was able to confirm 
Table 1 Prevalence of hepatitis C virus by ELISA

\begin{tabular}{lll}
\hline OD $/ C O$ & Number of positives & Prevalence (\%) \\
\hline$\geq 1$ & 42 & 3.2 \\
$\geq 2$ & 19 & 1.5 \\
$\geq 3$ & 12 & 0.9 \\
$\geq 4$ & 12 & 0.9 \\
\hline
\end{tabular}

OD: optical density; CO: cut-off.

Table 2 Agreement between recombinant immunoblot assay (RIBA) and ELISA tests according to the OD/CO readings

\begin{tabular}{llll}
\hline RIBA & \multicolumn{3}{l}{ Results of ELISA OD/CO $(N(\%))$} \\
\cline { 2 - 4 } & $\geq 1$ & $\geq 2$ & $\geq 3$ \\
\hline Positive & $13(31.0)$ & $12(63.2)$ & $12(100)$ \\
Undetermined & $18(42.9)$ & $6(31.6)$ & $0(0)$ \\
Negative & $11(26.2)$ & $1(5.3)$ & $0(0)$ \\
Total & 42 & 19 & 12 \\
\hline
\end{tabular}

OD: optical density; CO: cut-off.

all the results that were positive by ELISA with an optical density/cut-off $(O D / C O) \geq 3$ (Table 2$)$. The specificity of RIBA was $100 \%$ when testing seven negative ELISA samples, which were AgHBs positive (four) and anti-HAV IgM positive (three).

HCV RNA was detected (Figure 1) in ten RIBA-positive samples, three indeterminate RIBA samples and four negative RIBA samples, which would result in a prevalence of $1.3 \%$ $(17 / 1308)$. The final prevalence was $1.5 \%$ (20/1308) when the three positive RIBA samples that did not show detectable HCV RNA were included (Table 3). The study variables for the 20 positive individuals are described in Table 4.

Genotyping was successfully performed on 15 of the 17 HCV RNA positive serum samples. The test demonstrated a predominance of the genotype $3(8 / 15)$, followed by genotypes $1(6 / 15)$ and $2(1 / 15)$. It was not possible to determine the genotype in two samples owing to insufficient material.

Prevalence was nine times greater among those aged 35 years or older $(\mathrm{OR}=9.18,95 \% \mathrm{Cl} 3.02-27.90)$. In fact, there were only four positive individuals below 35 years of age. Females appear to have a higher prevalence, but this was not statistically significant compared with males. Those with less education had a lower prevalence than those with more education $(\mathrm{OR}=0.16,95 \% \mathrm{Cl} 0.05-0.50)$, as did those with lower income and poorer living conditions. However the numbers are small for the last two variables and are not statistically significant (Table 5 ).
$\begin{array}{llllllllllll}M & 1 & 2 & 3 & 4 & 5 & 6 & 7 & 8 & 9 & 10 & 11\end{array}$

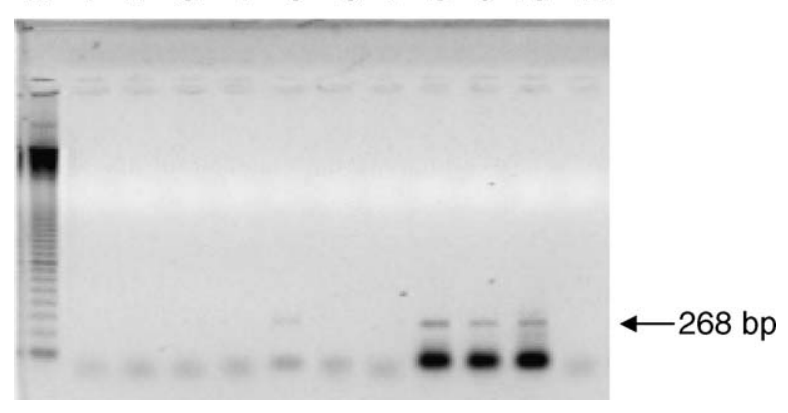

Figure 1 Detection of hepatitis C virus RNA in 1.5\% agarose gel. M: base pair marker ladder $123 \mathrm{bp}$; 1 : negative control; $2-4$ and 6-7: samples with negative results; 5, 8 and 9: samples with positive results; 10: positive control; 11: negative control ( $\mathrm{mix}=\mathrm{PCR}+$ water).

\section{Discussion}

In Latin America, local experiences have been developed for monitoring health problems by selecting intra-urban spaces referred to as 'sentinel areas'. This strategy was used in Salvador, Brazil, with the objective of evaluating the impact of different diseases on the health of the population (Killinger et al., 2000; Teixeira et al., 2002). Results from these studies already point to the great potential of the strategy, supporting the city's epidemiological surveillance with previously unknown information, enhancing the analyses of the health situation, and fostering the development of special epidemiological studies.

The overall prevalence of HCV infection was $1.5 \%$ $(20 / 1308)$ in a large sample of individuals of all ages $(6$ months to 98 years) from 30 sentinel surveillance areas in Salvador. Initially, a prevalence of $3.2 \%$ was observed in our study by ELISA. However, when the RIBA confirmatory test and RT-PCR were used, the final prevalence fell to $1.5 \%$, which was expected in a low-risk population where the number of false-positives tests for ELISA is high. This prevalence is almost the same as that found in the municipal district of Sao Paulo, which was $1.4 \%$ using the same confirmatory tests to identify cases (Focaccia et al., 1998). Our study also demonstrated an HCV prevalence close to that found by Silva et al. in 1995 of $1.25 \%$ in Salvador with confirmation only by RIBA (Silva et al., 1995). The inability to perform RT-PCR at that time could explain the slightly lower prevalence found in that study.

In 1998 , the city of Salvador had approximately 2.3 million inhabitants. If we extrapolate the prevalence of $1.5 \%$ to the general population of Salvador, considering that the

Table 3 Comparison of results of RT-PCR for hepatitis C virus RNA with ELISA and recombinant immunoblot assay (RIBA) tests

\begin{tabular}{|c|c|c|c|c|c|c|}
\hline \multirow[t]{2}{*}{ RT-PCR } & \multicolumn{3}{|c|}{ Results of ELISA OD/CO (N (\%)) } & \multicolumn{3}{|c|}{ Results of RIBA (N (\%)) } \\
\hline & $\geq 1$ & $\geq 2$ & $\geq 3$ & Negative & Undetermined & Positive \\
\hline Detectable & $17(40.5)$ & $12(63.2)$ & $10(83.3)$ & $4(36.4)$ & $3(16.7)$ & $10(76.9)$ \\
\hline Undetectable & $25(59.5)$ & $7(36.8)$ & $2(16.6)$ & 7 (63.6) & $15(83.3)$ & $3(23.1)$ \\
\hline Total & 42 & 19 & 12 & 11 & 18 & 13 \\
\hline
\end{tabular}


Table 4 Characteristics of the 20 hepatitis C virus positive individuals in Salvador (1998)

\begin{tabular}{|c|c|c|c|c|c|c|}
\hline Individual & Age (years) & Sex & Education (years) & Income (MW) & Neighbourhoods & Genotype \\
\hline 1 & 19 & Male & $<7$ & $\leq 2.5$ & WLC & 3 \\
\hline 2 & 35 & Female & $\geq 7$ & $\leq 2.5$ & WLC & NR \\
\hline 3 & 45 & Male & $\geq 7$ & $>2.5$ & BLC & 1 \\
\hline 4 & 32 & Female & $\geq 7$ & $>2.5$ & BLC & 3 \\
\hline 5 & 59 & Female & $<7$ & $\leq 2.5$ & WLC & 3 \\
\hline 6 & 47 & Female & $\geq 7$ & $>2.5$ & WLC & NA \\
\hline 7 & 35 & Male & $\geq 7$ & NA & WLC & NA \\
\hline 8 & 33 & Female & $<7$ & $\leq 2.5$ & WLC & 1 \\
\hline 9 & 40 & Female & $\geq 7$ & $>2.5$ & WLC & 1 \\
\hline 10 & 36 & Male & $\geq 7$ & $>2.5$ & WLC & 3 \\
\hline 11 & 36 & Female & $\geq 7$ & $>2.5$ & WLC & 3 \\
\hline 12 & 48 & Female & $\geq 7$ & $>2.5$ & BLC & 3 \\
\hline 13 & 56 & Female & $\geq 7$ & $>2.5$ & BLC & NA \\
\hline 14 & 35 & Female & $\geq 7$ & $>2.5$ & BLC & NR \\
\hline 15 & 30 & Male & $<7$ & $\leq 2.5$ & BLC & 1 \\
\hline 16 & 38 & Female & $\geq 7$ & $>2.5$ & WLC & 3 \\
\hline 17 & 55 & Male & $\geq 7$ & NA & WLC & 2 \\
\hline 18 & 47 & Female & NA & NA & NA & 3 \\
\hline 19 & 47 & Female & $\geq 7$ & $>2.5$ & BLC & 1 \\
\hline 20 & 38 & Male & $\geq 7$ & NA & WLC & 1 \\
\hline
\end{tabular}

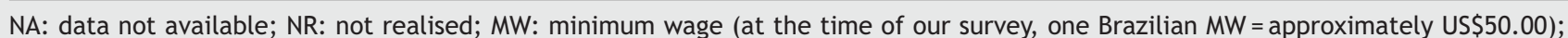
BLC: better living conditions; WLC: worse living conditions. Note: 2 of 17 HCV RNA positive samples were not genotyped.

samples were randomly selected within the sentinel areas and that they represent the various types of living conditions of the population, we can estimate a maximum of 34500 individual HCV virus carriers. Of these, 24150 (70\%) could develop chronic hepatitis, from which 4830 (20\%) could develop cirrhosis, and of these 386 (8\%) could develop hepatocellular carcinoma after approximately 20 years of infection.
In the PCR assay, HCV RNA was found in $40.5 \%$ of the samples that were positive by ELISA (17/42), where ten of these were positive by RIBA, three were indeterminate and four were negative by RIBA. The latter probably represent individuals at the beginning of infection or those with immunosuppression, since the HCV RNA was confirmed positive. The percentage of HCV RNA positivity could have been underestimated, since only one sample from each individual

Table 5 Univariate analysis of study variables and hepatitis C virus (HCV) infection in Salvador (1998)

\begin{tabular}{|c|c|c|c|c|c|}
\hline Variable & $N$ & HCV positive $(N(\%))$ & $95 \% \mathrm{Cl}$ & OR & $95 \% \mathrm{Cl}$ \\
\hline \multicolumn{6}{|l|}{ Age (years) } \\
\hline $0.5-34$ & 901 & $4(0.4)$ & & & \\
\hline $35-99$ & 407 & $16(3.9)$ & & 9.18 & $3.02-27.90$ \\
\hline \multicolumn{6}{|l|}{ Sex } \\
\hline Male & 553 & 7 (1.3) & $0.56-2.70$ & 1.00 & \\
\hline Female & 755 & $13(1.7)$ & $0.96-3.01$ & 1.37 & $0.54-3.45$ \\
\hline \multicolumn{6}{|l|}{ Education $^{\mathrm{a}}$} \\
\hline$\geq 7$ years & 428 & $15(3.5)$ & $2.05-5.84$ & 1.00 & \\
\hline$<7$ years & 680 & $4(0.6)$ & $0.19-1.61$ & 0.16 & $0.05-0.50$ \\
\hline \multicolumn{6}{|c|}{ Income $(M W)^{a}$} \\
\hline$>2.5$ & 538 & $10(1.9)$ & $0.95-3.51$ & 1.00 & \\
\hline$\leq 2.5$ & 599 & $4(0.7)$ & $0.41-2.28$ & 0.53 & $0.19-1.48$ \\
\hline \multicolumn{6}{|c|}{ Neighbourhood ${ }^{\mathrm{a}}$} \\
\hline BLC & 242 & $7(2.9)$ & $1.27-6.12$ & 1.00 & \\
\hline WLC & 965 & $12(1.2)$ & $0.67-2.23$ & 0.42 & $0.16-1.09$ \\
\hline
\end{tabular}

OR: odds ratio; $M W$ : minimum wage (approximately US\$50.00); BLC, better living conditions; WLC, worse living conditions.

a There were missing data for these variables for some subjects. 
was analysed. Moreover, the RNA can be present intermittently. This does not exclude the possibility of a chronic infection in the individuals who were RIBA positive or undetermined but who did not show RNA in the sample analysed (Krug et al., 1996). Moreover, these samples were previously manipulated, which could have resulted in undetectable RNA.

We were able to genotype 15 of the 17 samples that were HCV RNA positive. The genotype of the other two samples could not be determined owing to insufficient material. We verified a higher frequency of genotype 3 (53.3\%), followed by genotypes $1(40 \%)$ and $2(6.7 \%)$. This is in contrast to the genotype distribution observed by Silva et al. (2000) in a study conducted on HCV antibody positive individuals followed in ambulatory clinics and hospitals in Salvador, where a higher prevalence of genotype $1(62.7 \%)$ followed by genotypes $3(21.7 \%)$ and 2 (3.6\%) was found. The difference observed in the two previous studies could be attributed to the difference in study design, such as observed in Italy where Guadagnino et al. (1997) found a higher prevalence of genotype $2(44.6 \%)$ in the general population than in patients with chronic disease. Krug et al. (1996) observed that the prevalence of genotype $3(37 \%)$ was higher than expected, in contrast to the majority of data published in southern Brazil, among patients who were HCV RNA positive in Porto Alegre. However, the prevalence of genotype 1 (55\%) was still higher than genotype $3(37 \%)$ or $2(8 \%)$. Because the number of positive cases was small, new studies are necessary to confirm the high frequency of genotype 3 in Salvador.

Analysing the data among subgroups of the population, we observed a statistically significant association with age of 35 years and older compared with those with below 35 years. Other studies show evidence that the number of cases increases with age, especially after 30 years of age (Alter et al., 1999; Focaccia et al., 1998). In fact, in our data there was only one person infected at age 19 years and all the others were 30 years or older. This increase in prevalence is probably a combined result of an age effect and the greater risk of infection among females. Another possible explanation could be a combination of a period, cohort and age effect. Indeed, the higher proportion of infection among older groups might also reflect past infection during times of greater risk (cohort effect). Injection drug use is much less prevalent in the north-east region compared with the south-east region of Brazil and it is not common among the more affluent individuals of the north-east.

We found a greater number of females among the infected, but this was not statistically different compared with males. The association of HCV with gender is not clear. Silva et al. (1995) did not find any significant association between HCV and gender in Salvador. In a study in the general population in the city of São Paulo, Brazil, Focaccia et al. (1998) also did not find any difference in the prevalence of HCV between females and males. However, in Italy Guadagnino et al. (1997) observed a significant association with the female population, and in Egypt Nafeh et al. (2000) demonstrated a higher prevalence in males. In this community, HCV is a major problem and has been associated with parenteral treatment for schistosomiasis (El-Sayed et al., 1997). The prevalence is almost the same in the rural and urban populations, which is in agreement with these findings (El Gohary et al., 1995).
Regarding educational level, in our population we found a greater prevalence of HCV among individuals with $\geq 7$ years of education. It is worth noting that the level of education in our data does not record beyond 11 years. We also found a greater prevalence among those living in neighbourhoods with better living conditions and better income level, although this was not statistically significant. These three variables (education, income and neighbourhood) are proxies for socio-economic status, and in our data it appears that HCV is more prevalent among those with better socioeconomic status but not necessarily rich. However, the numbers are small and the reason for the association with higher socio-economic status in Salvador is not clear. Since genotype of HCV has a significant association with response to therapy, it is important from a public health perspective and for planning to have a good prevalence estimate. Therefore, it is important to choose carefully survey populations that accurately reflect the global population.

\section{Conflicts of interest statement}

The authors have no conflicts of interest concerning the work reported in this paper.

\section{Acknowledgements}

We thank Dr Bernardo Galvão and Aída Maria Costa for laboratory support; Mrs Maria Helena Rios and Dr Juarez Dias for data bank management; Mr Noilson Lázaro for sample centrifugation and separation; and Mr Damásio Paixão for help with the ELISA tests. We also wish to acknowledge Dr Ronald Blanton and Dr Lee Riley for careful reading and reviewing of the manuscript. Financial support was received from PRONEX/CNPq, CADCT, FIOCRUZ, SESAB/LACEN.

\section{References}

Alter, M.J., Kruszon-Moran, D., Nainan, O.V., McQuillan, G.M., Gao, F., Moyer, L.A., Richard, B.S., Kaslow, A., Margolis, M.D., 1999. The prevalence of hepatitis C virus infection in the United States, 1988 through 1994. N. Engl. J. Med. 341, 556-562.

Chomezynski, P., Sacchi, N., 1987. Single-step method of RNA isolation by acid guanidinium thiocyanate-phenol-chloroform extraction. Anal. Biochem. 162, 156-159.

Cochran, W.C., 1977. Sampling techniques, third ed. John Wills \& Sons, New York.

Davidson, F., Simmonds, P., Ferguson, J.C., Jarvis, L.M., Dow, B.C., Follet, E.A.C., Seed, C.R.G., Krusius, T., Lin, C., Megyesi, C.A., Kiyokawa, H., Olim, G., Dusaisamy, G., Cuypers, T., Saeed, A.A., Teo, D., Conradie, J., Kew, M.C., Lin, M., Muchaprayoon, C., Ndimble, O.K., Yap, P.M.L., 1995. Survey of major genotypes and subtypes of hepatitis $C$ virus using RFLP of sequences amplified from the $5^{\prime}$ non-coding region. J. Gen. Virol. 76, 1197-1204.

Di Lallo, D., Miceli, M., Petrosillo, N., Perucci, C.A., Moscatelli, M., 1999. Risk factors of hepatitis $C$ virus infection in patients on hemodialysis: a multivariate analysis based on a dialysis register in Central Italy. Eur. J. Epidemiol. 15, 11-14.

EASL, 1999. EASL International Consensus Conference on Hepatitis C. Paris, 26-28, February 1999, Consensus Statement. European Association for the Study of the Liver. J. Hepatol. 30, 956-961.

El Gohary, A., Hassan, A., Nooman, Z., Lavanchy, D., Mayerat, C., El Ayat, A., Fawaz, N., Gobran, F., Ahmed, M., Kawano, F., Kiyokawa, T., Yamaguchi, K., 1995. High prevalence of hepatitis $C$ virus among urban and rural population groups in Egypt. Acta Trop. 59, 155-161. 
El-Sayed, H.F., Abaza, S.M., Mehanna, S., Winch, P.J., 1997. The prevalence of hepatitis $B$ and $C$ infections among immigrants to a newly reclaimed area endemic for Schistosoma mansoni in Sinai, Egypt. Acta Trop. 68, 229-237.

Focaccia, R., da Conceicao, O.J.G., Junior, H.S., Sabino, E., Bassit, L., Nitrin, D.R., Lomar, A.V., Lorenço, R., Souza, F.V., Kiffer, C.R.V., Santos, E.B., Gonzales, M.P., Saes-Alquézar, A., Riscal, J.R., Fisher, D., 1998. Estimated prevalence of viral hepatitis in the general population of the Municipality of Sao Paulo, measured by a serologic survey of a stratified, randomized and residence-based population. Braz. J. Infect. Dis. 2, 269-284.

Fundação IBGE, 1996. Brazil Censo demográfico, Rio de Janeiro.

Guadagnino, V., Stroffolini, T., Rapicetta, M., Costantino, A., Kondili, L.A., Menniti-Ippolito, F., Caroleo, B., Costa, C., Griffo, G., Loiacono, L., Pisani, V., Foca, A., Piazza, M., 1997. Prevalence, risk factors, and genotype distribution of hepatitis $C$ virus infection in the general population: a community-based survey in southern Italy. Hepatology 26, 1006-1011.

Killinger, C.L., Góes, J.C., Menezes, E.A., 2000. Etnografia do saneamento, limpeza e saúde: um estudo de caso nas unidades domésticas. Ciência \& Saúde Coletiva 5 (Suppl. 83).

Krajden, M., 2000. Hepatitis C virus diagnosis and testing. Can. J. Public Health Suppl. 1, S34-S42.

Krug, L.P., Lunge, V.R., Ikuta, N., Fonseca, A.S., Cheinquer, H., Ozaki, L.S., 1996. Hepatitis C virus genotypes in Southern Brazil. Braz. J. Med. Biol. Res. 29, 1629-1632.

Li, J.S., Tong, S.P., Vitvitski, L., Trepo, C., 1995. Single-step nested polymerase chain reaction for detection of different genotypes of hepatitis C virus. J. Med. Virol. 45, 151-155.

Ministério da Saúde, Brasil, 1993. Sangue. Bol. Epidemiol. 2, 31.

Nafeh, M.A., Medhat, A., Shehata, M., Mikhail, N.N.H., Swifee, Y., Abdel-Hamid, M., Watts, S., Fix, A.D., Strickland, G.T., Anwar,
W., Sallam, I., 2000. Hepatitis C in a community in Upper Egypt: I. Cross-sectional survey. Am. J. Trop. Med. Hyg. 63, 236-241.

Nousbaum, J.B., 1998. Genomic subtypes of hepatitis C virus: epidemiology, diagnosis and clinical consequences. Bull. Soc. Pathol. Exot. 91, 29-33.

Oliveira, M.L., Bastos, F.I., Sabino, R.R., Paetzold, U., Schreier, E., Pauli, G., Yoshida, C.F., 1999. Distribution of HCV genotypes among different exposure categories in Brazil. Braz. J. Med. Biol. Res. 32, 279-282.

Roggendorf, M., Meisel, H., Viazov, S., 2000. Natural history of hepatitis C. Mem. Inst. Oswaldo Cruz 95, 189-192.

Sambrook, J., Fritsch, E.F., Maniatis, T., 1989. Molecular Cloning: a Laboratory Manual. Cold Spring Harbor Laboratory Press, Cold Spring Harbor, NY.

Schreier, E., Roggendorf, M., Driesel, G., Hohne, M., Viazov, S., 1996. Genotypes of hepatitis $C$ virus isolates from different parts of the world. Arch. Virol. Suppl. 11, 185-193.

Silva, L., Paraná, R., Mota, E., Cotrim, H.P., Boennec-McCurtey, M.L., Vitvitinsky, L., Padua, A., Trepo, C., Lyra, L., 1995. [Prevalence of hepatitis $C$ virus in urban and rural populations of northeast Brazil - pilot study.] Arq. Gastroenterol. 32, 168-171 [in Portuguese].

Silva, L.K., Paraná, R., Souza, S.P., Berby, F., Kay, A., Trepo, C., Santana, N., Cotrim, H., Lyra, L.G., Reis, M.G., 2000. Hepatitis $\mathrm{C}$ virus genotypes in a northeastern area of Brazil. Am. J. Trop. Med. Hyg. 62, 257-260.

Teixeira, M.G., Barreto, M.L., Costa, M.C.N., Strina, A., Martins Jr, D., Prado, M., 2002. Sentinel areas: a monitoring strategy in public health. Cad. Saúde Pública 18, 1189-1195.

Tong, M.J., el-Farra, N.S., Reikes, A.R., Co, R.L., 1995. Clinical outcomes after transfusion-associated hepatitis C. N. Engl. J. Med. 332, 1463-1466. 